\title{
The Analysis of Infant Death Determinants in Aceh Besar Regency of 2019
}

\author{
Nilawati $^{1}$, Nurjannah ${ }^{2}$, Said Usman ${ }^{3}$, Irwan Saputra ${ }^{4}$, Bakhtiar $^{5}$ \\ 1,2,3,4 Magister Program of Public Health, Faculty of Medicine, Universitas Syiah Kuala, Indonesia \\ ${ }^{5}$ Department of Pediatrics, Faculty of Medicine, Universitas Syiah Kuala, Indonesia \\ nilawati1978@yahoo.co.id,nurjannah_dr@unsyiah.ac.id, saidusman@unsyiah.ac.id, \\ iwanbulba@unsyiah.ac.id, bakhtiar@unsyiah.ac.id
}

\begin{abstract}
This study deals with the analysis of infant death determinants in Aceh Besar Regency of 2019. One effort to get people to care and know a lot about their health and that of their families well needs a health literacy program. Pregnant women who have low health literacy reduce the success of early pregnancy detection efforts and increase the risk of death in infants or complications. This study is conducted by quantitative design using analytical methods with a Case Control approach. The result shows that there are relationship inter variables. And the most dominant variable in causing infant mortality in Aceh Besar Regeny of 2019 is socioeconomic.
\end{abstract}

Keywords

infant death; determinants, Aceh

\section{Introduction}

Maternal mortality rate (MMR) and infant mortality rate (IMR) are important indicators for assessing a country's welfare level and public health status. Most infant deaths occur at an early age, infant mortality at an early age is closely related to the health status of the mother during pregnancy (Abdiana, 2015). Early death in infants is also related to the level of knowledge of mothers and families about the importance of antenatal care and is supported by the role of health workers and the availability of health facilities is very helpful in preventing maternal death and infant death. One of the causes of high neonatal mortality in infants aged 8-28 days is infection (tetanus, sepsis, pneumonia and diarrhea) (Kusuma, 2012).

Causes of early neonatal death or death in the first week of birth are premature birth, asphyxia and congenital defects. The cause of advanced neonatal death is infection. The indirect cause of neonatal death is low birth weight associated with premature birth or Intrauterine Growth Retardation (IUGR) (Latifah, 2012). In addition, early neonatal mortality is also related to maternal health and health services, which are determinants for children's survival. High and low neonatal mortality depends on various risk factors such as the level of maternal knowledge that is also related to the actions obtained by the mother during obstetric care during pregnancy, the socioeconomic level that is often associated with the birth of low birth weight babies, the quality of prenatal care, age pregnant women, maternal occupations, parity, habits of pregnant women consuming cigarettes and alcohol, pregnancy disorders, complications, asphyxia, history of maternal illness and infection (Noviani A., 2011).

Some studies also prove that the main cause of infant mortality and maternal death is a factor of mother and family knowledge. Lack of knowledge of pregnant women about midwifery services that must be performed during pregnancy will affect the health of the mother and her baby (Latifah, 2012). Knowledge of pregnant women will influence the behavior of pregnant women to want to do a pregnancy check up to the health service to be 
able to monitor the growth of the baby, maternal health and detect as early as possible abnormalities or complications that occur in infants so that prevention can be done (Imelda, 2018).

One effort to get people to care and know a lot about their health and that of their families well needs a health literacy program. Pregnant women who have low health literacy reduce the success of early pregnancy detection efforts and increase the risk of death in infants or complications (Nurfaila, 2012). Health literacy also provides interventions such as simplified information and illustrations, avoiding jargon, re-teaching methods and encouraging patient questions and improving low public health behavior (White A., 2008).

Health literacy is one of the solutions to problems in pregnant women, especially those who have a high risk of pregnancy. Lack of health literacy causes late detection of pregnancy so that health problems and complications that occur in mothers and babies are too late to be known and treated so that the increase in mortality and morbidity. Factors related to the health literacy of pregnant women in undergoing antenatal care are maternal age, maternal education, mother's occupation, mother's motivation, the role of health workers and family support (White A., 2008).

\section{Review of Literatures}

\subsection{Infant Death}

The definition of death is generally defined as an event of the permanent disappearance of signs of life that can occur any time after a live birth, and one of the signs of life that determines a person is alive or dead is a heartbeat (Hamidah S, 2009). According to the official statement of IDA (Indonesian Doctors Association), a person is declared dead if:

1. The spontaneous function of breathing and heart has stopped definitively

2. It has been proven that IDA's brain stem dies (Indonesian Doctors Association) (2010).

The sex compositions of a population play a vital role in the population analysis, since it affects the incidence of births, deaths, and marriage. The migration rates and almost all population characteristics, including socio-economic characteristics, community life are influenced by the sex composition of population, and are in turn affected by these attributes (Ahmad Andrabi, 2018).

Meanwhile, according to WHO, death is a state of disappearance of all signs of life that can occur permanently any time after a live birth. Born alive is the result of the conception from a mother's womb completely without regard to the length of the pregnancy and after the separation occurred (Noviani, 2010). Live birth according to WHO is the birth of a baby regardless of the length of time in the womb, where the baby shows signs of life, such as breathing, heart rate or WHO muscle movements (2013).

Still Birth is the death of a baby with a gestational age of 28 weeks or more, but coming out of the uterus there are no signs of life. Infant death is the death of a child of less than one year. Infant mortality is measured as the infant mortality rate which is the number of child deaths below one per 1000 live births (Syarief R, 2003). According to WHO stillbirth is the birth of a baby whose time is enough when it comes out of the uterus without any signs of life such as, the absence of a heartbeat, no breathing and no muscle movement WHO (2013).

\subsection{Health Literacy}

The National Assessment of Adults Literacy in the United States uses the definition of Health Literacy or health awareness, the ability to use written and printed health information to be used in the community to achieve its goals, and to develop its knowledge and potential. 
These abilities include the ability to read drug labels, health information brochures, informed consent, understand information provided by health workers and the ability to carry out instructions and treatment procedures (White A., 2008).

Health literacy is generally associated with one's reading and writing abilities. This is consistent with the definition of health literacy stated by The American Medical Association which represents the biomedical model as the ability to read and understand prescription drugs, medical cards and other forms of material that relate to his role as a patient (Hadiswi \& Suminar, 2017). Knowledge and cultural concepts surrounding the concept of health literacy so far have been interpreted as a person's ability to understand the meaning of health, the meaning of pain, the risks and benefits. But behind this, the above concept also includes the role of health providers in communicating effectively with patients to encourage participation in a healthy lifestyle through patient-centered communication (Delsarte \& Genin, 1991).

Numeric or arithmetic related to the ability to understand nutritional information that is in the packaging of food or drug products, also related to the ability to understand the dosage of drugs that must be taken for treatment, and also related to the selection of insurance or health insurance. Health providers who are more experienced in communicating with patients should be able to help patients to understand information related to this numeric. Thus it can be said that health literacy depends on characteristics of both parties in the health care system (Hadisiwi \& Suminar, 2017).

The World Health Organization in the Health Promotion Glossary defines Health literacy, namely cognitive and social abilities that determine the motivation and ability of individuals to gain access, understand and use information in ways that improve and maintain good health by increasing access and capacity of the community to obtain and use health information effectively, Health literacy plays a role in empowerment (WHO, 2003).

\section{Research Methods}

This research will be carried out with a quantitative design using analytical methods with a Case Control approach. Starting with the identification of patients who have an outcome that is the respondent who has a baby died at the age before 1 year is referred to as a case, and the group without the outcome is called the control ie respondents who do not have a baby die before 1 year old. By retrospectively tracing measured risk factors by looking at past events related to research (Wibowo, 2014).

This research will be carried out in 23 Subdistricts consisting of 28 Community Health Centers in Aceh Besar Regency Health Office in 2019. The population in this study is all mothers of infants aged <1 year in Aceh Besar Regency in 2019 namely 9,694 people. Using a Case control design using a comparison between case samples and 1: 1 control samples.

The case sample in this study used all mothers who had babies who died at $<1$ years old in 2019 in Aceh Besar Regency. While the control sample would be matched with cases on domicile and parity, taken with purposive sampling, namely mothers who have babies under 2 years.

\section{Data Processing Method}

Univariate analysis was performed to provide a descriptive description of each variable used. All variables are categorical data, then univariate analysis produces frequency distribution, namely the dependent variable is infant mortality, the independent variables are health literacy, maternal age, socioeconomic conditions, education, Antenatal Care (ANC) service, access to health facility transportation, LBW, Premature and Exclusive breastfeeding (Wibowo A, 2014). 
Bivariate analysis to determine the relationship between independent variables with the dependent variable without considering other independent variables. In this study, health literacy variables, maternal characteristics consisting of maternal age, socioeconomic and educational conditions, Antenatal Care (ANC) services, access to health facility transportation, infant condition consisting of low birth weight (LBW), premature and exclusive breast milk associated with infant mortality variables using the Chi Square Test. Chi Square testing compares the frequency that occurs with the frequency of expectations. If the Chi Square test requirements do not meet (at least in 1 cell 5) the Fisher exact test will be used. The analysis used with the SPSS computer program with a significant level of $95 \%$.

Multivariate analysis was conducted to determine the likelihood of the occurrence of the dependent variable being influenced in addition to the risk factor exposure to the main variable also jointly influenced by other variables. Because the dependent variable is categorical and aims to validly estimate the relationship of risk factors of the main independent variable with the dependent variable and several confounder variables, the analysis used is multiple logistic regression (Wibowo A, 2014).

\section{Discussion}

Data collection was carried out on March 23 to April 23, 2020 in Aceh Besar Regency, with the following mechanism: on Monday March 23, data were collected on infants who were stillborn and still alive. Furthermore, mothers from the case group (dead babies) were given a questionnaire as well as mothers from the control group (live babies). After completing the data collection, the data is then processed according to the case group and the control group.

This univariate analysis is an analysis of the research variables in the form of frequency distributions and is presented in a percentage table of the variable characteristics of the infant mother by case group and control group.

\subsection{Characteristics of Toddler Mothers}

Table 1. Frequency Distribution of Mother Baby Characteristics

\begin{tabular}{|c|c|c|c|c|c|}
\hline \multirow{2}{*}{ No. } & \multirow{2}{*}{ Characteristics } & \multicolumn{2}{|c|}{ Cases (30) } & \multicolumn{2}{|c|}{ Controls (30) } \\
\hline & & $\mathbf{n}$ & $\%$ & $\mathbf{n}$ & $\%$ \\
\hline \multirow{3}{*}{1.} & Aged & & & & \\
\hline & Risked & 12 & 40 & 2 & 6,7 \\
\hline & Unrisked & 18 & 60 & 28 & 93,3 \\
\hline \multirow{3}{*}{2.} & Education & & & & \\
\hline & Moderate & 21 & 70 & 17 & 56,7 \\
\hline & High & 9 & 30 & 13 & 43,3 \\
\hline \multirow{3}{*}{3.} & Social Economy & & & & \\
\hline & Low & 24 & 80 & 12 & 40 \\
\hline & High & 6 & 20 & 18 & 60 \\
\hline
\end{tabular}

Source: Data Processing Results (2020)

Based on the age of known baby mothers in the majority of case groups are in the age group at risk by $60.0 \%$, while the control group is mostly in the non-risk group that is $93.3 \%$. Based on the variables of the baby's mother's education it is known that in the case group the majority of mothers with secondary education is $40.0 \%$ while in the control group the majority are highly educated at $43.3 \%$. In the socioeconomic variable it is known that most of 
the baby mothers who are in the low educated case group is $80.0 \%$ while the majority in the control group has a high socioeconomic category that is $60 \%$.

\subsection{ANC Services}

ANC services are health services provided by health workers to mothers during a child's pregnancy who are the subject of research. The ANC service indicator is complete if it meets the 10T standard and is incomplete if it does not meet the 10T standard.

Table 2. Frequency Distribution of ANC Service Case and Control Group

\begin{tabular}{clcccc}
\hline \multirow{2}{*}{ No. } & \multirow{2}{*}{ Service of ANC } & \multicolumn{2}{c}{ Cases } & \multicolumn{2}{c}{ Controls } \\
\cline { 3 - 6 } & & $\mathbf{n}$ & $\mathbf{\%}$ & $\mathbf{n}$ & $\mathbf{\%}$ \\
\hline 1. & Complete & 22 & 73,3 & 10 & 33,3 \\
2. & Incomplete & 8 & 26,7 & 20 & 66,7 \\
\hline \multicolumn{2}{|c}{ Total } & 30 & 100 & 30 & 100,0 \\
\hline
\end{tabular}

Source: Data Processing Results (2020)

Table 2 shows that in the case group there were $73.3 \%$ of mothers who did not complete ANC, and in the control group the majority of $66.7 \%$ did complete ANC.

\subsection{Transportation Access}

Transportation access in this study is a health facility that is taken by someone to obtain health services, which are classified as easy and difficult

Table 3. Frequency Distribution of Transportation Access in Case and Control Groups

\begin{tabular}{clcccc}
\hline \multirow{2}{*}{ No. } & \multirow{2}{*}{ Transportation Access } & \multicolumn{2}{c}{ Cases } & \multicolumn{2}{c}{ Controls } \\
\cline { 3 - 6 } & & $\mathbf{n}$ & $\mathbf{\%}$ & $\mathbf{n}$ & $\boldsymbol{\%}$ \\
\hline 1. & Difficult & 18 & 60 & 11 & 36,7 \\
2. & Easy & 12 & 40 & 19 & 63,3 \\
\hline \multicolumn{2}{l}{ Total } & 30 & 100 & 30 & 100 \\
\hline
\end{tabular}

Source: Data Processing Results (2020)

Table 3 shows that in the case group there were $60 \%$ of mothers who had difficulty getting access to transportation when they were going to delivery, and in the control group there were $36.7 \%$ who had difficulty getting transportation access when they were going to labor.

\subsection{Low Birth Weight}

Variables of low birth weight of infants are grouped into premature and dismature. The results of complete data processing can be seen in the following table

Table 4. Frequency Distribution of Low Birth Weight in Case and Control Group

\begin{tabular}{clcccc}
\hline \multirow{2}{*}{ No. } & \multirow{2}{*}{ Low Birth Weight } & \multicolumn{2}{c}{ Cases } & \multicolumn{2}{c}{ Controls } \\
\cline { 3 - 6 } & & n & \% & n & \% \\
\hline 1. & Premature & 22 & 73,3 & 17 & 56,7 \\
2. & Dismature & 8 & 26,7 & 13 & 43,3 \\
\hline \multicolumn{2}{l}{ Total } & 30 & 100 & 30 & 100 \\
\hline
\end{tabular}

Source: Data Processing Results (2020) 
Table 4 shows that most mothers in the case group gave birth to premature babies (73.3\%), and in the control group 56.7\% gave birth to premature babies.

\subsection{Exclusive Breastfeeding}

Exclusive breastfeeding variables are grouped into exclusive and non-exclusive. The results of complete data processing can be seen in the following table

Table 5. Frequency Distribution of Exclusive breastfeeding in Case and Control Groups

\begin{tabular}{clcccc}
\hline \multirow{2}{*}{ No. } & \multirow{2}{*}{ Exclusive Breastfeeding } & \multicolumn{2}{c}{ Cases } & \multicolumn{2}{c}{ Controls } \\
\cline { 3 - 6 } & & $\mathbf{n}$ & $\boldsymbol{\%}$ & $\mathbf{n}$ & $\boldsymbol{\%}$ \\
\hline 1. & Non-exclusive & 21 & 70.0 & 18 & 60 \\
2. & Exclusive & 9 & 30 & 12 & 40 \\
\hline \multicolumn{2}{l}{ Total } & 30 & 100 & 30 & 100 \\
\hline
\end{tabular}

Source: Data Processing Results (2020)

Table 5 shows that the majority of mothers in the case group did not give breast milk exclusively to their babies $(70.0 \%)$ and in the control group there were $60.0 \%$ of mothers who did not give breast milk exclusively to their babies.

\subsection{Health Facilities Access}

Health facilities access in this study is respondent access to health facilities to get maternal and child health services. The results of complete data processing can be seen in the following table.

Table 6. Frequency Distribution of Health Facilities Access in Case and Control Group

\begin{tabular}{|c|c|c|c|c|c|}
\hline \multirow{2}{*}{ No. } & \multirow{2}{*}{ Access Health Facilities } & \multicolumn{2}{|c|}{ Cases } & \multicolumn{2}{|c|}{ Controls } \\
\hline & & $\mathbf{n}$ & $\%$ & $\mathbf{n}$ & $\%$ \\
\hline 1. & Less & 20 & 66,7 & 11 & 36,7 \\
\hline 2. & Good & 10 & 33,3 & 19 & 63,3 \\
\hline & Total & 30 & 100 & 30 & 100 \\
\hline
\end{tabular}

Source: Data Processing Results (2020)

Table 6 shows that most of the mothers in the case group said that access to health facilities was not good $(66.7 \%)$ and in the control group there were $36.7 \%$ of mothers who had access to poor health facilities.

\subsection{Health Literacy}

Health literacy is the ability to use child health information. The results of complete data processing can be seen in the following table

Table 7. Frequency Distribution of Health Literacy in Case and Control Groups

\begin{tabular}{cllcccc}
\hline \multirow{2}{*}{ No. } & \multirow{2}{*}{ Health Literacy } & \multicolumn{2}{c}{ Cases } & \multicolumn{2}{c}{ Controls } \\
\cline { 3 - 6 } & & $\mathbf{n}$ & $\mathbf{\%}$ & $\mathbf{n}$ & $\mathbf{\%}$ \\
\hline 1. & Less & 17 & 56,7 & 7 & 23,3 \\
2. & Good & 13 & 43,3 & 23 & 76,7 \\
\hline & Total & 30 & 100 & 30 & 100 \\
\hline
\end{tabular}

Source: Data Processing Results (2020) 
Table 7 shows that most of the mothers in the case group had poor health literacy $(56.7 \%)$ and in the control group there were $23.3 \%$ of mothers who had poor health literacy.

\subsection{Relationship between Various Factors and Infant Mortality}

Bivariate analysis was carried out on several risk factor variables that were thought to be related to infant mortality in Aceh Besar Regency. Bivariate analysis using Odds Ratio (OR) and Confidence Interval (CI) 95\%. OR to determine the magnitude of risk between maternal age, socioeconomic, education, ANC services, access to transportation, LBW, exclusive breastfeeding, access to health facilities and health literacy for infant mortality.

a. The Relationship between Maternal Age and Infant Mortality in Aceh Besar Regency

The relationship of maternal age in the case and control groups with death is shown in the following table:

Table 8. The Relationship between maternal age and infant mortality in Aceh Besar Regency

\begin{tabular}{|c|c|c|c|c|c|c|}
\hline Aged & Cases & Controls & Total & Odds ratio (OR) & P Value & CI 95\% \\
\hline Risked & $12(40,0 \%)$ & $2(6,7 \%)$ & $14(23,3 \%)$ & 9,33 & 0,007 & $1,86-46,68$ \\
Unrisked & $18(60,0 \%)$ & $28(93,3 \%)$ & $46(76,7 \%)$ & & & \\
\hline
\end{tabular}

Source: Data Processing Results (2020)

Table 8 shows that there is a relationship between maternal age and infant mortality in the case and control groups ( $\mathrm{p}<0.05)$ with an odds ratio of 9.33 (95\% CI = $1.86-46.68)$, meaning that mothers who have age at risk 9.3 greater chance of giving birth to a baby in a dead condition compared to mothers of age who are not at risk.

b. The Relationship betwee Socio-Economic and infant mortality in Aceh Besar Regency

The socioeconomic relationship in the case and control groups with death is shown in the following table:

Table 9. The Relationship betwee Socio-Economic and infant mortality in Aceh Besar

Regency

\begin{tabular}{|c|c|c|c|c|c|c|}
\hline $\begin{array}{c}\text { Socio- } \\
\text { Economic }\end{array}$ & Cases & Controls & Total & Odds ratio (OR) & P Value & CI 95\% \\
\hline Low & $24(80,0 \%)$ & $12(40,0 \%)$ & $36(60,0 \%)$ & 6,00 & 0,002 & $1,89-19,04$ \\
High & $6(20,0 \%)$ & $18(60,0 \%)$ & $24(40,0 \%)$ & & & \\
\hline
\end{tabular}

Source: Data Processing Results (2020)

Table 9 shows that there is a relationship between socioeconomic and infant mortality in the case and control groups ( $\mathrm{p}<0.05)$ with an odds ratio of $6.00(95 \% \mathrm{CI}=1.89-19.04)$, meaning that mothers who have socioeconomic low tend to give birth to babies in the condition of death 6 times greater than mothers with high socioeconomic.

\section{c. The Relationship between Mother's Educations and Infant Mortality in Aceh Besar Regency}

The relationship of education in the case and control groups with death is shown in the following table: 
Table 10. The Relationship between Mother's Education and Infant Death in Aceh Besar Regency

\begin{tabular}{|c|c|c|c|c|c|c|}
\hline Education & Cases & Controls & Total & Odds ratio (OR) & P Value & CI 95\% \\
\hline Basic/Moderate & $21(70,0 \%)$ & $17(56,70 \%)$ & $38(63,3 \%)$ & 1,78 & 0,286 & $0,61-5,16$ \\
High & $9(30,0 \%)$ & $13(43,3 \%)$ & $22(36,7 \%)$ & & & \\
\hline
\end{tabular}

Source: Data Processing Results (2020)

Table 10 shows that there is no significant relationship between education and infant mortality in the case and control groups ( $\mathrm{p}>0.05)$ with an odds ratio of $1.78(95 \% \mathrm{CI}=0.61$ 5.16), meaning that mothers with primary / secondary education has a 1.78 times greater chance of delivering a baby in a dead condition compared to mothers with higher education.

\section{d. The Relationship between ANC Services and Infant Mortality in Aceh Besar Regency}

The relationship of ANC services in the case and control groups with mortality is shown in the following table:

Table 11. The Relationship between ANC Services and Infant Mortality in Aceh Besar

\begin{tabular}{|l|c|c|c|c|c|c|}
\hline ANC Services & Cases & Controls & Total & Odds ratio (OR) & pValue & CI 95\% \\
\hline Complete & $22(73,3 \%)$ & $10(33,3 \%)$ & $32(53,3 \%)$ & 5,50 & 0,003 & $1,81-16,68$ \\
Incomplete & $8(26,7 \%)$ & $20(66,7 \%)$ & $28(46,7 \%)$ & & & \\
\hline
\end{tabular}

Source: Data Processing Results (2020)

Table 11 shows that there is a relationship between ANC services and infant mortality in the case and control groups $(\mathrm{p}<0.05)$ with an odds ratio of $5.50(95 \% \mathrm{CI}=1.81-16.68)$, meaning that mothers who do not complete ANC examination has a 5.5 greater chance of giving birth to a baby in a dead condition compared to mothers who received complete ANC services.

\section{e. The Relationship between Transportation Access and Infant Mortality in Aceh Besar Regency}

The relationship of transportation access in the case and control groups with death is shown in the following table:

Table 12. The Relationship between Transportation Access and Infant Mortality in Aceh Besar Regency

\begin{tabular}{|l|c|c|c|c|c|c|}
\hline $\begin{array}{c}\text { Transportation } \\
\text { Access }\end{array}$ & Cases & Controls & Total & $\begin{array}{c}\text { Odds ratio } \\
(\text { OR) }\end{array}$ & pValue & CI 95\% \\
\hline Difficult & $18(60,0 \%)$ & $11(36,7 \%)$ & $29(48,3 \%)$ & 2,59 & 0,048 & $1,81-7,34$ \\
Easy & $12(40,0 \%)$ & $19(63,3 \%)$ & $31(51,7 \%)$ & & & \\
\hline
\end{tabular}

Source: Data Processing Results (2020)

Table 12 shows that there is a relationship between transportation access and infant mortality in the case and control groups $(\mathrm{p}<0.05)$ with an odds ratio of $2.59(95 \% \mathrm{CI}=1.81$ 7.34), meaning that mothers have access Difficult transportation tends to give birth to a baby in a 2.5-fold greater condition than mothers with easy transportation access. 
f. The relationship between Low Birth Weight and Infant Mortality in Aceh Besar Regency

The relationship of Low Birth Weight in the case and control groups with death is shown in the following table:

Table 13. The relationship between Low Birth Weight and Infant Mortality in Aceh Besar Regency

\begin{tabular}{|c|c|c|c|c|c|c|}
\hline BBLR & Cases & Controls & Total & Odds ratio (OR) & pValue & CI 95\% \\
\hline Premature & $22(73,3 \%)$ & $17(56,7 \%)$ & $39(65,0 \%)$ & 2,10 & 0,179 & $0,71-6,22$ \\
Dismature & $8(26,7 \%)$ & $13(43,3 \%)$ & $21(35,0 \%)$ & & & \\
\hline
\end{tabular}

Source: Data Processing Results (2020)

Table 13 shows that there is no significant relationship between Low Birth Weight and infant mortality in the case and control groups ( $p>0.05)$ with an odds ratio of $2.10(95 \% \mathrm{CI}=$ 0.71-6.22), meaning that the mother giving birth premature babies tend to give birth to babies in the condition of death 2 times greater than mothers who give birth to baby dismature.

g. The Relationship between Exclusive Breastfeeding and Infant Mortality in Aceh Besar Regency

The relationship of exclusive breastfeeding in the case and control groups with death is shown in the following table:

Table 14. The Relationship between Exclusive breastfeeding and infant mortality in Aceh Besar Regency

\begin{tabular}{|c|c|c|c|c|c|c|}
\hline ASI Exclusive & Cases & Controls & Total & Odds ratio (OR) & P Value & CI 95\% \\
\hline Unexclusive & $21(70,0 \%)$ & $18(60,0 \%)$ & $39(65 \%)$ & 1,55 & 0,04 & $1,73-4,53$ \\
Exclusive & $9(30,0 \%)$ & $12(40,0 \%)$ & $21(35 \%)$ & & & \\
\hline
\end{tabular}

Source: Data Processing Results (2020)

Table 14 shows that there is a relationship between exclusive breastfeeding and infant mortality in the case and control groups ( $\mathrm{p}<0.05)$ with an odds ratio of $1.55(95 \% \mathrm{Ci}=1.73$ 4.53), meaning that mothers who do not exclusive breastfeeding tends to give birth to a baby in a death condition 1.5 times greater than mothers who exclusively breastfeed.

\section{h. The Relationship between Health Facilities Access and Infant Mortality in Aceh} Besar Regency

The relationship of access to health facilities in the case and control groups with mortality is shown in the following table:

Table 15. The Relationship between Health Facilities Access and Infant Mortality in Aceh Besar Regency

\begin{tabular}{|c|c|c|c|c|c|c|}
\hline Health Facility & Cases & Controls & Total & Odds ratio (OR) & P Value & CI 95\% \\
\hline Less & $20(66,7 \%)$ & $11(36,7 \%)$ & $31(51,7 \%)$ & 3,45 & 0,022 & $1,19-9,99$ \\
Good & $10(33,3 \%)$ & $19(63,3 \%)$ & $29(48,3 \%)$ & & & \\
\hline
\end{tabular}

Source: Data Processing Results (2020)

Table 15 shows that there is a relationship between health facilities access and infant mortality in the case and control groups ( $\mathrm{p}<0.05)$ with an odds ratio of $3.455(95 \% \mathrm{CI}=$ $1,195-9,990)$, meaning that mothers who have less access to health facilities good chance 3.45 times more likely to give birth to a baby in a dead condition compared to mothers with access to good health facilities. 
i. The Relationship between Health Literacy and infant mortality in Aceh Besar Regency

The relationship of health literacy in the case and control groups with death is shown in the following table:

Table 16. The Relationship between Health Literacy and Infant Mortality in Aceh Besar

\begin{tabular}{|c|c|c|c|c|c|c|}
\hline Health Facility & Cases & Controls & Total & Odds ratio (OR) & P Value & CI 95\% \\
\hline Less & $17(56,7 \%)$ & $7(23,3 \%)$ & $24(40,0 \%)$ & 4,29 & 0,010 & $1,41-13,06$ \\
Good & $13(43,3 \%)$ & $23(76,7 \%)$ & $36(60,0 \%)$ & & & \\
\hline
\end{tabular}

Source: Data Processing Results (2020)

Table 16 shows that there is a relationship between health literacy and infant mortality in the case and control groups ( $\mathrm{p}<0.05)$ with an odds ratio of 4.29 (95\% CI $=1.41-13.06)$, meaning that mothers with literacy Poor health has a 4.29 greater chance of giving birth to a baby in a dead condition compared to mothers with poor health literacy

\subsection{Multiple Logistic Regression Test}

Inferential statistical analysis in research uses logistic regression analysis (logistic regression). In this study the dependent variable is dichotomous (dead baby or live baby), then testing the hypothesis is done using logistic regression test. Logistic regression is a regression used to test whether the probability of occurrence of related variables can be explained by the independent variable. In the logistic regression analysis technique no longer requires the normality test and the classic assumption test on the independent variable (Ghozali, 2011). The stages in testing using the logistic regression test can be explained as follows:

\section{a. Overall Model Fit}

The first analysis conducted was to assess the overall model fit contained research data as research as shown in table 17

Table 17. Omnibus Test Results

\begin{tabular}{|l|l|r|r|r|}
\hline \multicolumn{5}{|c|}{ Omnibus Tests of Model Coefficients } \\
\cline { 2 - 5 } \multicolumn{2}{|c|}{} & Chi-square & df & \multicolumn{1}{c|}{ Sig. } \\
\hline \multirow{3}{*}{ Step 1 } & Step & 68,949 & 9 & 0,000 \\
\cline { 2 - 5 } & Block & 68,949 & 9 & 0,000 \\
\cline { 2 - 5 } & Model & 68,949 & 9 & 0,000 \\
\hline
\end{tabular}

Omnibus test results are known that the value of sig. the model is 0,000 which means that with a confidence level of 95 percent, there is at least one independent variable that affects the dependent variable, so it can be concluded that the model can be used for further analysis. 


\section{b. Coefficient of Determination (Nagelkerke R Square)}

Based on data from table 18 below, Nagelkerke R Square value of 0.911 , which means the dependent variable can be explained by an independent variable of $91.1 \%$, while the remaining $8.9 \%$ is explained by other variables regulated by the research model. This shows that together the variation of independent variables namely maternal age, socioeconomic, LBW, ANC services, health facilities, exclusive breastfeeding and health literacy can explain variations in infant mortality variables by $91.1 \%$.

Table 18. Nagelkerke R Square Value

\begin{tabular}{|c|c|c|c|}
\hline \multicolumn{4}{|c|}{ Model Summary } \\
\hline Step & $\begin{array}{c}-2 \text { Log } \\
\text { likelihood }\end{array}$ & $\begin{array}{c}\text { Cox \& Snell R } \\
\text { Square }\end{array}$ & Nagelkerke R Square \\
\hline 1 & $14,229^{\mathrm{a}}$ &, 683 & 911 \\
\hline
\end{tabular}

\section{c. Classification Matrix}

The classification matrix shows the predictive power of the regression model to predict the likelihood of infant death in Aceh Besar Regency. Based on data from table 4.17 below shows that the predictive power of the regression model to predict the likelihood of stillbirths in Aceh Besar Regency is $90 \%$. The predictive power of the regression model to predict the likelihood of a baby being born alive is $80 \%$. While the overall predictive power of the regression model in this study was $85.0 \%$. This means that the predictive ability of the model with statistically independent variables can predict the dependent variable of $85.0 \%$.

Table 19. Classification Matrix

\begin{tabular}{|c|c|c|c|c|c|}
\hline \multicolumn{6}{|c|}{ Classification Table $^{\mathbf{a}}$} \\
\hline \multirow{3}{*}{\multicolumn{3}{|c|}{ Observed }} & \multicolumn{3}{|c|}{ Predicted } \\
\hline & & & \multicolumn{2}{|c|}{ Infant Death } & \multirow{2}{*}{$\begin{array}{c}\text { Percentage } \\
\text { Correct }\end{array}$} \\
\hline & & & Die & Life & \\
\hline \multirow[t]{3}{*}{ Step 1} & \multirow[t]{2}{*}{ Infant Death } & Die & 19 & 11 & 63,3 \\
\hline & & Life & 8 & 22 & 73,3 \\
\hline & \multicolumn{2}{|c|}{ Overall Percentage } & & & 68,3 \\
\hline
\end{tabular}

\section{d. Formed Logistics Regression Models and Hypothesis Testing}

The logistic regression model can be formed by looking at the estimated value of the parameters in Variables in the Equation in table 20 below:

Table 20. Logistic Regression

\begin{tabular}{|l|c|c|c|c|}
\hline \multirow{2}{*}{\multicolumn{1}{c|}{ Variables }} & & \multicolumn{2}{c|}{ 95\% C.I.for EXP(B) } \\
\cline { 4 - 5 } & p-value & OR & Lower & Upper \\
\hline Mother's age & 0,058 & 8.42 & 0,92 & 76,50 \\
\hline Socio-economic Status & 0,025 & 8.91 & 1,32 & 60,5 \\
\hline ANC Service & 0,009 & 11.21 & 1,83 & 68,38 \\
\hline Transportation Access & 0,044 & 6.85 & 1,057 & 44,43 \\
\hline Health Literacy & 0,006 & 12.31 & 2,11 & 83,65 \\
\hline
\end{tabular}


Table 20 shows that after simultaneous testing by releasing variables that did not pass the prerequisites for a regression test with $p>0.25$, it was simultaneously obtained that health literacy (Litkes) was a factor affecting infant mortality in Aceh Besar Regency $(p \leq 0.05)$. Based on the calculation results it is known that the most dominant factor causing infant death in Aceh Besar Regency is health literacy factor $(p=0.006 \leq 0.05)$. The results of this study support the first hypothesis which states that health literacy has an effect on infant mortality in Aceh Besar Regency.

\section{Conclusion}

Based on the results of data processing, it can be concluded as follows:

1. There is a relationship between maternal health literacy and infant mortality in Aceh Besar Regency of 2019

2. There is a relationship between maternal age and infant mortality in Aceh Besar Regency of 2019

3. There is a relationship between the socio-economic situation of the family and infant mortality in Aceh Besar Regency of 2019

4. There is a relationship between maternal education and infant mortality in Aceh Besar Regency of 2019.

5. There is an Antenatal Care (ANC) service relationship with infant deaths in Aceh Besar Regency of 2019.

6. There is a connection between access to health facilities and infant mortality in Aceh Besar Regency of 2019.

7. There is a relationship between low birth weight babies (LBW) with infant deaths in Aceh Besar Regency of 2019.

8. There is a relationship between exclusive breastfeeding and infant mortality in Aceh Besar Regency of 2019.

9. There is a relationship between accesses to health facilities with infant mortality in Aceh Besar Regency of 2019.

10. The most influential or most dominant variable in causing infant mortality in Aceh Besar Regency of 2019 is socioeconomic.

\section{References}

Ahmad Andrabi, J. (2018). A Spatio-Temporal Analysis of Sex-Ratio in Districts of Jammu and Kashmir, India. Budapest International Research and Critics Institute-Journal (BIRCI-Journal), 1(3): 183-191.

Abdiana, 2015, 'Determinan Kematian Bayi di Kota Payakumbuh'. Jurnal Kesehatan Masyarakat Andalas, Sumatera Barat, Vol. 12, hh. 89-93.

Amalina, S 2015, Analisis Faktor Penyebab Bayi Lahir dengan Berat Badan Lahir Rendah. Tesis. UI, Jakarta.

Arinita, 2012, Analisis Kejadian Kematian Bayi Akibat LOW BIRTH WEIGHT Dirumah Sakit Pusat DR.Mohammad Hoesin Palembang. Tesis. Universitas Indonesia, Jakarta.

Dharmalingam, 2010, 'Nutritional Status of Mother and Low Birth Weight In India.' Maternal and Child Health Jurnal. Vol. 14, hh. 290-298.

Delsarte \& Genin, 1991, 'An Introduction to the Class of Split Levinson Algorithms.' Journal Health Literacy. Vol. 9, hh. 240-254.

Depkes RI, 2001, Pedoman Pelayanan Antenatal Care di Tingkat Pelayanan Dasar. Dir. Jend Bina Kesehatan Keluarg, Jakarta. 
Djaja, 2009, 'Kehamilan dan Persalinan Pada Kematian Dini Akibat Aksfiksia Lahir Sebelum dan Setelah Intervensial Kabupaten Cirebon.' ejournal.litbang.depks.go.id. Diunduh 9 Oktober 2019.

Festy, 2009, Bayi dengan Berat Badan Lahir Rendah. Mulia Medika. Tesis. Yogyakarta.

Hadiswi \& Suminar, 2017, 'Literasi Kesehatan Masyarakat Dalam Menompang Pembangunan Kesehatan Di Indonesia.' Jurnal Komunikasi. Vol. 10, hh. 114-119.

Hamidah S, 2009. Kebidanan Komunitas. EGC, Jakarta.

Imelda, F 2018, 'Faktor Risiko Kematian Dini di Kabupaten Kepulauan Mentawai.' Jurnal Kajian Ilmiah Problema Kesehatan, Vol 4 No 1.

Irma, 2009, Hubungan Karakteristik dengan Health Literacy Mahasiswa Universitas Dian Nuswantoro. Tesis. Semarang.

Kemenkes RI, 2010, Buku Panduan Tata Laksana Bayi Baru Lahir di Rumah Sakit. Kementrian Kesehatan, Jakarta.

Kemenkes RI, 2011, Glosarium Data dan Informasi Kesehatan. Pusat Data dan Surveilans Epidemiologi, Jakarta.

Kemenkes RI, 2019, Kematian Maternal dan Dini di Indonesia Fakultas Kesehatan Masyarakat Universitas Indonesia. Kementerian Kesehatan, Banten.

Khannal, 2014, 'Role of Antenatal Care and Iron Suplemmentation during Pregnancy in Preventing Low Birth Weigh in Nepal.' Archives of Public Health.

Kusuma, A 2012, 'Faktor Penyebab Kematian Bayi di Sidoarjo.' Jurnal Biometrika dan Kependudukan, Vol.1 No 1. 204-217.

Latifah, N 2012, Hubungan Frekuensi Kunjungan ANC Selama Kehamilan dengan Kejadian Kematian Dini. Fakultas Kesehatan Masyarakat. Jakarta.

Manuaba, 2010, Ilmu Kebidanan Penyakit Kandungan dan KB untuk Pendidikan Bidan. EGC, Jakarta.

Noviani, 2011, Hubungan Berat Badan Lahir Rendah dengan Kejadian Kematian Dini di Indonesia. Universitas Indonesia. Jakarta.

Nurfaila, 2012, Pengenalan Faktor-Faktor Risiko Deteksi Dini Ibu Hamil Risiko Tinggi. Airlangga University Press, Surabaya.

Nursalam, 2006, Manajemen Keperawatan: Aplikasi Dalam Praktik Keperawatan Professional. Salemba Medika, Jakarta.

Pretty, 2016, Hubungan Self Management dengan Kualitas Hidup Pasien Diabetes Mellitus di Puskesmas Pisangan Ciputat. Universitas Islam Syarif Hidayatullah, Jakarta.

Priyadi, P 2008, 'Analisi Faktor Risiko Kematian Dini.' Jurnal Promosi Kesehatan Indonesia, Vol 3, No 1. Bibliography $\backslash 11033$

Sistriani, 208, Hubungan Antara Pelayanan Kesehatan Ibu Hamil dan Kematian Perinatal di RSPAD Gatot Subroto. Tesis. Bidang Ilmu Kesehatan Masyarakat. Program Pascasarjana Universitas Indonesia, Jakarta.

Sumantri A, 2012, Metodologi Penelitian Kesehatan. Pradana Media, Jakarta.

Sundeen, 2007, Buku Saku Keperawatan Jiwa. Edisi 3. EGC, Jakarta.

Suriati, 2002, Faktor-Faktor Yang Berhubungan dengan Kejadian LOW BIRTH WEIGHT di Kabupaten Kotawaring. Universitas Gajah Mada, Yogyakarta.

Syarief R, 2003, Hubungan Kualitas Pelayanan Antenatal Care Terhadap Kejadian LOW BIRTH WEIGHT di Kabupaten Purworejo. UGM, Jogyakarta.

Vitrianingsih, 2012, 'Hubungan Kualitas Pelayanan Antenatal Care Terhadap Kematian Bayi di Kabupaten Purworejo.' Jurnal Sains Kesehatan Vol. 17, No. 2, pp. 209-220.

Wahyu Ningtyas, 2013, Analisis Kualitas Hidup Pasien di RSUD Bangil Kabupaten Pasuruan. Universitas Indonesia. Tesis, Jakarta. 
White, 2008, Assessing the Nations Health Literacy: Key Concepts and Findings of National Assessment of Adult Literacy. AMA Foundation.

White, 2010, Addressing Health Literacy and Numeracy to Improve Education and Care. Spectrum.

WHO, 2013, Growth References 5-19 Years for Adolescense. Diunduh dari http://www.who.int//growthrwfwrwncws5-19yearsforadolescense2007-pdf// pada tanggal 20 September 2019.

WHO, 2003, Who Expert Comitte on Pregnancy, Meeting Held in Geneva. World Health Organization.

Wibowo, A. 2014, Metodologi Praktis Bidang Kesehatan. PT Grafindo Persada, Jakarta. 